\title{
A MEDIAÇÃO NOS CONFLITOS AMBIENTAIS
}

Congresso Brasileiro Online de Ciências Contábeis, 1a edição, de 04/10/2021 a 06/10/2021 ISBN dos Anais: 978-65-89908-97-5

\section{AZEVEDO; FERNANDA FREITAS DE OLIVEIRA ${ }^{1}$}

\section{RESUMO}

Entre as formas de se chegar a um consenso para a resolução de conflitos, a mediação é tem sido considerada uma ferramenta pautada com as políticas judiciais nacionais e tem tido grande destaque. No entanto, é necessário melhorar a mediação em determinadas áreas (como a área ambiental). A investigação coletiva reflete o possível desequilíbrio de poder entre os mediadores em processos de direito ambiental, e tem como objetivo analisar a necessidade de proteção nacional no âmbito da mediação ambiental de acordo com os regulamentos autorizados pelo $\mathrm{CPC} / 2015$. Este estudo visa compreender em que medida a mediação, enquanto conceito de consenso judicial (não polêmico), pode atender aos requisitos para uma melhor distribuição da justiça em conflitos ambientais. O problema a ser resolvido é entender a finalidade da mediação como a finalidade de resolução de conflitos ambientais, ou seja, ela só pode mediar danos ambientais individuais e coletivos (disponíveis e negociáveis), ou se pode mediar direitos ambientais (mesmo que se propaguem Fatos Acima, os conflitos neste campo envolvem os direitos básicos e descentralizados das gerações presentes e futuras, portanto, todas as partes em conflito não podem desistir. Especula-se que o uso da mediação e seus métodos inerentes à resolução de conflitos ambientais podem trazer enormes benefícios ao processo e promover o desenvolvimento sustentável, pois o instituto significa o cumprimento de exigências ambientais, não só restaurativas, mas também sexuais preventivas. Por este motivo, esta pesquisa é realizada sob a qualidade de métodos de revisão de literatura utilizando métodos descritivos, analíticos e explicativos. Como técnica de exposição desta pesquisa, o mapeamento da literatura foi utilizado em pesquisas que buscam comprovar o uso da mediação na resolução de conflitos ambientais. Acredita-se que os protagonistas da disputa e seus operadores jurídicos são essenciais para mediar o conhecimento das possibilidades prósperas pactuadas entre nós. O novo código de processo resolve esse problema em vários dispositivos. O novo procedimento reflete totalmente a diferença entre mediação e mediação, e requer pesquisa e compreensão mais aprofundadas do assunto do processo. Devem ser tomadas medidas para encorajar a mediação para prevenir abusos que incentivem a intimidação e minem o verdadeiro consenso. Além disso, o direito internacional mostra a validade desta disposição. Portanto, a mediação ambiental internacional tem como características promover o diálogo, participar do processo e promover a cooperação, a unidade e a solidariedade dos povos de todos os países, e se tornou um instrumento utilizado principalmente por todos os países 
para prevenir, construir e manter a paz. Os mediadores atuam em todos os níveis do conflito, formando uma rede de mediadores. Nesse sentido, deve-se esclarecer que embora políticas públicas tenham sido propostas, elas ainda parecem políticas secundárias, pois pode-se supor que o foco nos setores econômicos parece mais evidente. Olhando para os exemplos dos residentes ao longo dos rios Riachão e Pau D'óleo, onde os conflitos ocorreram recentemente, não há dúvida de que se justificam pressupostos que mesmo através da mediação de políticas e estratégias de conflitos, o Estado acaba por assumir o papel de conflito facilitador.

PALAVRAS-CHAVE: Conflito ambiental, Dano social, Mediação, Responsabilidade Socioambiental 